\section{The Meanng in life And Depression Level Among Student}

\author{
Happy Cahaya Mulya, Tri Kurniati Ambarini \\ Fakultas Psikologi, \\ Universitas Airlangga, Surabaya \\ Email : happycahmul@gmail.com
}

Journal PSIKODIMENSIA

Volume 18, No. 2,

Juni - Desember 2019

ISSN cetak : 1411-6073

ISSN online : $2579-6321$

DOI 10.24167/psidim.v18i2.2151

\begin{abstract}
The aim of this study is to understand the relationship between meaning in life and depression levels of university students. Additionally, this study also aims to understand the relationship between the two aspects of meaning in life with depression levels. This study was done on 254 students using LRI-R to measure meaning in life and BDI-II Indo Version to measure level of depression. Data analysis technique used in this study is kendall tau_b. The result of this study shows that meaning in life has a negative relationship with level of depression on university students. Apart from that, this study also shows that both aspects of meaning in life, framework and fulfillment, have negative relationships with depression levels.
\end{abstract}

Keywords: Depression levels, Meaning in Life, University Students.

\section{PENDAHULUAN}

Mahasiswa merupakan salah satu kalangan yang rentan mengalami permasalahan terkait kesehatan mental. Tanggung jawab hidup yang semakin besar dan tuntutan akademik yang meningkat membuat mahasiswa mengalami situasi yang semakin berat dalam hidupnya (Santrock, 2013). Ketidakmampuan untuk menghadapi hal tersebut dapat membuat mahasiswa mudah mengalami permasalahan-permasalahan psikologis.

Survei yang dilakukan oleh The Insight Network and Dig in (2019) menunjukkan bahwa $21,5 \% \quad(n=37.500)$ mahasiswa terdiagnosis mengalami permasalahan terkait kesehatan mental. Berdasarkan survei tersebut, depresi merupakan salah satu gangguan mental yang banyak terjadi pada mahasiswa dengan prosentase sebesar 10,2\%. Hal ini didukung pula oleh penelitian lain di beberapa negara yang mendapatkan bahwa pravelensi terjadinya depresi pada mahasiswa berada pada angka 27,1\% $(\mathrm{n}=1617)$ di Turki (Bayram \& Bilgel, 2008), 33\% ( $n=9743)$ di Iran (Sarokhani et al., 2013), dan 29,4\% $(\mathrm{n}=1017)$ di Malaysia (Islam, Low, Tong, Choo, \& Yuen, 2018).

Depresi sendiri merupakan salah satu gangguan mental yang ditandai dengan adanya perubahan spesifik pada suasana hati (seperti, sedih, kesepian, dan apatis), konsep diri yang negatif pada seseorang, terjadinya regresi dan pemikiran untuk menghukum diri sendiri, adanya perubahan vegetative, serta penurunan level aktivitas (Beck \& Alford, 2009). Gangguan ini dapat berdampak buruk bagi kehidupan mahasiswa, contohnya seperti prestasi akademik yang menurun, penyalahgunaan zat terlarang, munculnya gejala gangguan psikologis lain, hingga bunuh diri (Khurshid, Parveen, Yousuf, \& Chaudhry, 2015; Moreno et al., 2011). 
Devivere (2018) menjelaskan bahwa depresi dapat terjadi karena seseorang tidak memiliki makna dalam hidupnya. Setiap individu memiliki motivasi utama yaitu pencarian dan pemenuhan makna hidup. Ketika seseorang berhasil menemukan dan memenuhi makna hidupnya, maka individu tersebut akan merasa puas terhadap kehidupannya. Di sisi lain, jika seseorang tidak mampu untuk menemukan dan memenuhi makna hidupnya, maka individu tersebut dapat merasa hampa, tidak memiliki harapan, dan bahkan kehilangan keinginan untuk hidup.

Battista dan Almond mendefinisikan makna hidup sebagai sebuah keyakinan individual bahwa dirinya telah memenuhi kerangka atau tujuan hidup yang memberikan pengertian sangat berharga bagi dirinya. Seseorang dikatakan memiliki makna hidup yang tinggi ketika memiliki komitmen terhadap sebuah konsep tentang makna hidup, memiliki sebuah kerangka hidup, memandang hidupnya memiliki tujuan, dan merasakan pemenuhan dari tujuan tersebut.

Berdasarkan konsep tersebut, Battista dan Almond (1973) mengembangkan teori mengenai makna hidup yang terdiri dari dua aspek, yaitu framework dan fulfillment. Aspek Framework merujuk pada kemampuan seseorang untuk melihat hidupnya dalam suatu perspektif atau konteks dan menurunkannya dalam suatu tujuan hidup atau cara pandang hidup bagi dirinya. Aspek Fulfillment dilihat sebagai pandangan seseorang mengenai keberhasilannya untuk memenuhi kerangka hidup yang dimilikinya.

Damon (2008, dalam Santrock, 2013) menjelaskan bahwa makna hidup merupakan salah satu hal penting bagi seorang mahasiswa yang notabene berada pada masa perkembangan dewasa awal. Tanggung jawab untuk menjadi semakin mandiri dalam menentukan arah hidup membuat mahasiswa perlu menentukan kerangka hidup dan berusaha memenuhi hal tersebut. Keberhasilan dalam memenuhi kerangka hidup tersebut menjadikan dirinya memiliki makna hidup yang tinggi, sebaliknya kegagalan dalam memenuhi kerangka hidup tersebut dapat membuat mahasiswa merasa tidak berguna yang memunculkan gejala-gejala depresi.

Penelitian yang dilakukan oleh Meiyuntari dan Utomo (2015) pada 93 mahasiswa mendapatkan bahwa makna hidup memiliki hubungan yang negatif dengan tingkat depresi. Hasil yang serupa juga didapatkan dari penelitian yang dilakukan oleh Hedayati dan Khazaei (2014) serta Kleftaras dan Psarra (2012), yaitu seseorang dengan makna hidup tinggi memiliki tingkat depresi yang rendah, sebaliknya seseorang yang memiliki makna hidup rendah memiliki tingkat depresi yang tinggi.

Tujuan dari penelitian ini adalah melihat hubungan makna hidup dengan tingkat depresi pada mahasiswa. Selain itu, penelitian ini juga ingin melihat hubungan antara kedua aspek makna hidup, yaitu cara pandang seseorang terhadap kerangka hidupnya dan pandangan terhadap keberhasilan dalam memenuhi kerangka hidupnya terhadap tingkat depresi pada mahasiswa.

\section{METODE}

Penelitian ini merupakan penelitian kuantitatif korelasional dengan menggunakan makna hidup sebagai variabel independen dan depresi sebagai variabel dependen. Subjek penelitian ini adalah mahasiswa dari sebuah universitas swasta di Surabaya. Pada penelitian ini, variabel makna hidup diukur dengan menggunakan LRI-R yang dibuat oleh 
Battista dan Almond (1973) dan direvisi oleh Debats (1996), sedangkan variabel tingkat depresi diukur dengan menggunakan BDI-II yang dikembangkan dalam Versi Indonesia oleh Ginting, Näring, Van Der Veld, Srisayekti, dan Becker (2013). Data yang didapatkan dianalisa dengan menggunakan teknik analisis data kendall tau_b karena terdapat uji asumsi yang tidak terpenuhi untuk dilakukan uji statistik parametrik, yaitu uji normalitas. Analisis data pada penelitian ini dilakukan dengan menggunakan IBM SPSS Statistics 22.
HASIL

Penelitian ini dilakukan pada 254 mahasiswa yang terdiri dari $74,02 \%$ mahasiswa perempuan dan $25,98 \%$ mahasiswa laki-laki. Subjek penelitian ini tersebar mulai dari usia 17 tahun hingga 26 tahun dengan prosentase terbesar pada usia $19(25,98 \%)$ dan 20 tahun $(25,98 \%)$. Subjek yang terlibat dalam penelitian ini terdiri dari mahasiswa tahun pertama hingga keempat dengan jumlah paling besar yaitu pada mahasiswa tahun pertama dengan prosentase sebesar 39,37\%. Secara rinci data disajikan pada tabel 1 .

Tabel 1. Karakteristik Subjek Penelitian

\begin{tabular}{llcc}
\hline Karakteristik & & Jumlah & Persentase \\
\hline Usia & 17 tahun & 6 & $2,36 \%$ \\
& 18 tahun & 65 & $25,59 \%$ \\
19 tahun & 66 & $25,98 \%$ \\
& 20 tahun & 66 & $25,98 \%$ \\
& 21 tahun & 33 & $12,99 \%$ \\
& $\geq 22$ tahun & 18 & $7,09 \%$ \\
& Total & $\mathbf{2 5 4}$ & $\mathbf{1 0 0 \%}$ \\
\hline Jenis Kelamin & Laki-laki & 66 & $25,98 \%$ \\
& Perempuan & 188 & $74,02 \%$ \\
& Total & $\mathbf{2 5 4}$ & $\mathbf{1 0 0 \%}$ \\
\hline Tahun Akademik & 1 & 100 & $39,37 \%$ \\
& 2 & 72 & $28,35 \%$ \\
& 3 & 77 & $30,31 \%$ \\
& $\geq 4$ & 5 & $1,97 \%$ \\
& Total & $\mathbf{2 5 4}$ & $\mathbf{1 0 0 \%}$ \\
\hline
\end{tabular}

Pada Tabel 2 terlihat sebaran makna

berdasarkan kategorinya.

hidup dan tingkat depresi pada mahasiswa

Tabel 2. Tabulasi Silang Makna Hidup dan Tingkat Depresi pada Mahasiswa

\begin{tabular}{|c|c|c|c|c|c|c|c|}
\hline & & \multicolumn{5}{|c|}{ Tingkat Depresi } & \multirow[b]{2}{*}{ Total } \\
\hline & & $\begin{array}{l}\text { Sangat } \\
\text { Rendah }\end{array}$ & Rendah & Sedang & Tinggi & $\begin{array}{l}\text { Sangat } \\
\text { Tinggi }\end{array}$ & \\
\hline \multirow{5}{*}{$\begin{array}{c}\text { Makna } \\
\text { Hidup }\end{array}$} & $\begin{array}{l}\text { Sangat } \\
\text { Rendah }\end{array}$ & $0(0 \%)$ & $0(0 \%)$ & $5(2,0 \%)$ & $5(2,0 \%)$ & $2(0,8 \%)$ & $12(4,7 \%)$ \\
\hline & Rendah & $0(0 \%)$ & $0(0 \%)$ & $21(8,3 \%)$ & $9(3,5 \%)$ & $4(1,6 \%)$ & $34(13,4 \%)$ \\
\hline & Sedang & $0(0 \%)$ & $26(10,2 \%)$ & $\begin{array}{c}128 \\
(50,4 \%)\end{array}$ & $11(4,3 \%)$ & $1(0,4 \%)$ & $166(65,4 \%)$ \\
\hline & Tinggi & $0(0 \%)$ & $16(6,3 \%)$ & $24(9,4 \%)$ & $2(0,8 \%)$ & $0(0 \%)$ & $42(16,5 \%)$ \\
\hline & $\begin{array}{l}\text { Sangat } \\
\text { Tinggi }\end{array}$ & $0(0 \%)$ & $0(0 \%)$ & $0(0 \%)$ & $0(0 \%)$ & $0(0 \%)$ & $\mathbf{0}(0 \%)$ \\
\hline \multicolumn{2}{|c|}{ Total } & $0(0 \%)$ & $42(16,5 \%)$ & $\begin{array}{c}178 \\
(70,1 \%)\end{array}$ & $27(10,6 \%)$ & $7(2,8 \%)$ & $254(100 \%)$ \\
\hline
\end{tabular}


Berdasarkan tabel 2 tersebut, terlihat bahwa mahasiswa dengan makna hidup yang sangat rendah memiliki tingkat depresi yang tersebar pada kategori sedang $(2,0 \%)$, tinggi $(2,0 \%)$, dan sangat tinggi $(2,0 \%)$. Mahasiswa dengan makna hidup rendah memiliki tingkat depresi yang tersebar pada kategori sedang $(8,3 \%)$, tinggi $(3,5 \%)$, dan sangat tinggi $(1,6 \%)$. Mahasiswa dengan makna hidup sedang memiliki tingkat depresi yang tersebar pada kategori rendah $(10,2 \%)$, sedang $(50,4 \%)$, tinggi $11(4,3 \%)$, dan sangat tinggi $(0,4 \%)$. Mahasiswa dengan makna hidup yang tinggi memiliki tingkat depresi yang tersebar pada kategori rendah $(6,3 \%)$, sedang $(9,4 \%)$, dan tinggi $(0,8 \%)$. Pada tabel tersebut juga terlihat bahwa tidak ditemukan mahasiswa yang memiliki makna hidup sangat tinggi. Selain itu, pada tabel 2 juga terlihat bahwa tidak ditemukan mahasisw ayang memiliki tingkat depresi sangat rendah pada penelitian ini.

Berdasarkan hasil penelitian yang telah dilakukan, didapatkan bahwa makna hidup memiliki hubungan negatif dengan tingkat depresi pada mahasiswa $(\mathrm{p}<0,01 ; \mathrm{r}=$ $0,285)$ dengan nilai koefisien determinasi sebesar $8,12 \%$. Selain itu, pada tabel 3 juga terlihat bahwa terdapat hubungan negatif yang signifikan antara aspek Framework dengan tingkat depresi pada mahasiswa $(\mathrm{p}<0,01 ; \mathrm{r}=-0,258)$ dengan nilai koefisien determinasi sebesar 6,66\%. Aspek Fullfilment juga memiliki hubungan yang negatif dengan tingkat depresi pada mahasiswa $(\mathrm{p}<0,01 ; \mathrm{r}=-0,283)$ dengan koefisien determinasi sebesar $8,009 \%$.

Tabel 3. Uji Statistik Hubungan Makna Hidup dan Tingkat Depresi pada Mahasiswa

\begin{tabular}{lcccc}
\hline & $\mathbf{1}$ & $\mathbf{2}$ & $\mathbf{3}$ & $\mathbf{4}$ \\
\hline 1. Tingkat Depresi & 1 & & & \\
2. Makna Hidup & $-0,285^{* *}$ & 1 & & \\
3. Framework & $-0,258^{* *}$ & $0,829^{* *}$ & 1 & \\
4. Fullfilment & $-0,283^{* *}$ & $0,830^{* *}$ & $0,626^{* *}$ & 1 \\
\hline Keterangan :**p $<0,01$ & & & &
\end{tabular}

Keterangan : $* * p<0,01$

\section{DISKUSI}

Berdasarkan hasil penelitian
yang telah dilakukan didapatkan bahwa makna hidup memiliki hubungan negatif dengan tingkat depresi pada mahasiswa. Hasil penelitian ini mendukung penelitan sebelumnya yang juga menemukan adanya hubungan negatif antara makna hidup dan tingkat depresi (Hedayati \& Khazaei, 2014; Kleftaras \& Psarra, 2012; Meiyuntari \& Utomo, 2015). Hal ini menunjukkan bahwa semakin rendah makna hidup yang dimiliki oleh mahasiswa maka semakin tinggi tingkat depresi yang dialaminya, sebaliknya semakin tinggi makna hidup yang dimiliki oleh mahasiswa maka semakin rendah tingkat depresi yang dialaminya.

Mahasiswa, sebagai seorang individu yang memasuki tahap perkembangan dewasa awal, memiliki kebutuhan yang tinggi untuk menemukan makna hidupnya (Damon, 2008 dalam Santrock, 2013). Salah satu aspek penting dalam tahapan tersebut adalah menemukan arah yang jelas terkait kerangka hidupnya. Pada penelitian ini didapatkan bahwa aspek framework memiliki hubungan negatif dengan tingkat depresi. Mahasiswa yang memiliki kerangka hidup yang 
jelas dapat meminimalkan munculnya gejala-gejala depresi. Di sisi lain, mahasiswa yang belum memiliki kerangka hidup yang jelas lebih rentan terhadap gejala-gejala depresi.

Schaefer dkk.

menjelaskan bahwa individu dengan tujuan atau kerangka hidup yang jelas memiliki kemampuan pemulihan emosional yang baik dalam menghadapi stimuli negatif. Tujuan atau kerangka hidup yang dimiliki oleh seseorang membuatnya mampu untuk menemukan pandangan yang positif terhadap pengalaman hidupnya, terutama dalam menghadapi tantangan di kehidupannya. Hal ini mengembangkan kemampuan seseorang dalam meregulasi emosinya sehingga membuatnya lebih resilien dalam menghadapi kejadian-kejadian negatif yang ditemuinya.

Devivere (2018) juga menyatakan bahwa motivasi utama manusia adalah pencarian makna hidup, yang digambarkan sebagai nilai-nilai penting bagi dirinya. Hal ini merupakan sesuatu yang unik dan spesifik yang hanya dapat serta harus dipenuhi oleh individu itu sendiri. Ketika seseorang tidak mampu untuk menemukan hal tersebut, ia akan merasa hampa, tidak memiliki harapan, bahkan kehilangan keinginan untuk hidup.

Aspek fulfillment pada makna hidup juga memiliki peran penting untuk mengurangi kemungkinan munculnya gejala-gejala depresi. Ketika seseorang memiliki pandangan bahwa dirinya telah berhasil memenuhi kerangka hidup atau hal-hal yang penting bagi dirinya maka ia akan merasa berharga yang kemudian meminimalkan terjadinya gejala-gejala depresi. Sebaliknya, ketika seseorang merasa tidak mampu untuk memenuhi kerangka hidupnya maka ia akan merasa tidak berharga dalam hidupnya.

Arnold-Baker

menjelaskan bahwa depresi disebabkan oleh perasaan tidak mampu untuk memenuhi kondisi yang "seharusnya" atau kondisi yang ingin dicapainya. Pada kondisi demikian, ia akan merasa kecewa terhadap diri sendiri yang umumnya diikuti dengan refleksi diri yang berlebihan terhadap ketidakmampuannya atau dapat disebut sebagai hyper-reflection (Marshall, 2011). Kondisi ini membuat seseorang menjadi semakin merasa tidak berguna, kondisi suasana hati yang menurun, hingga memunculkan gejala depresi lainnya.

Pemaparan di atas menjelaskan bahwa kedua aspek dari makna hidup saling berkaitan satu dengan lainnya terhadap tingkat depresi yang dialami oleh mahasiswa. Di sisi lain, hasil penelitian ini juga menemukan bahwa makna hidup dan kedua aspeknya hanya memiliki koefisien korelasi yang tergolong kecil terhadap tingkat depresi. Selain itu, hasil penelitian ini juga menunjukkan bahwa terdapat $0,8 \%$ mahasiswa yang memiliki makna hidup tinggi dengan tingkat depresi yang tergolong tinggi pula. Hal ini mengindikasikan bahwa makna hidup tidak dapat sepenuhnya menjelaskan tingkat depresi yang dialami oleh mahasiswa. Terdapat faktor-faktor lain yang juga dapat berpengaruh terhadap tingkat depresi pada mahasiswa. 
Bennett (2006) menjelaskan bahwa faktor sosio-kultural dapat mempengaruhi terjadinya depresi pada seseorang. Menurutnya, depresi lebih banyak terjadi pada individu yang berada pada sosio ekonomi rendah dan etnis-etnis monoritas. Selain itu, kondisi dimana dirinya tidak memiliki dukungan dari lingkungan juga berpengaruh terhadap terjadinya gejala-gejala depresi pada seseorang.

Islam dkk. (2018) juga menemukan bahwa mahasiswa yang tinggal jauh dari orangtuanya juga memiliki kemungkinan yang lebih besar untuk mengalami depresi dibandingkan mahasiswa yang tinggal bersama dengan orangtua. Menurutnya, mahasiswa yang tinggal jauh dari orangtua cenderung mengalami perasaan yang asing dengan lingkungannya sehingga merasa kehilangan dukungan sosial yang berada di sekitarnya.

Faktor lain yang dapat berpengaruh terhadap depresi adalah jenis kelamin. Bennett (2006) menjelaskan bahwa perempuan memiliki kemungkinan mengalami depresi yang lebih besar dibandingkan laki-laki. Hal ini dapat terjadi karena perempuan memiliki kecenderungan yang lebih besar untuk mengatribusi kegagalan yang dimilikinya dibandingkan dengan laki-laki. Selain itu, laki-laki juga memiliki kecenderungan untuk lebih mudah mendistraksi pemikiran-pemikiran negatif sehingga dapat lebih berfokus pada penyelesaian permasalahan dibandingkan dengan perempuan.

\section{SIMPULAN}

Berdasarkan penelitian yang dilakukan, dapat disimpulkan bahwa makna hidup memiliki hubungan negatif dengan tingkat depresi pada mahasiswa. Kedua aspek makna hidup, yaitu framework dan fulfillment juga memiliki hubungan negatif yang signifikan dengan tingkat depresi. Akan tetapi, hubungan antara makna hidup dan tingkat depresi memiliki koefisien korelasi yang tergolong kecil sehingga perlu adanya penelitian lanjutan yang juga melibatkan faktorfaktor lain dari tingkat depresi agar pemahaman mengenai hal tersebut dalam lebih komprehensif.

Berdasarkan hasil penelitian ini, beberapa saran yang dapat diberikan adalah:

1. Bagi penelitian berikutnya.

a. Pada penelitian berikutnya diharapkan faktor-faktor lain, seperti faktor sosiokultural, tempat tinggal, dan jenis kelamin dapat dipertimbangkan juga untuk menjadi bagian dari uji hubungan antara makna hidup dan tingkat depresi. Dengan demikian, penelitian berikutnya dapat memiliki hasil yang lebih komprehensif terhadap hubungan makna hidup dan tingkat depresi.

b. Penelitian berikutnya dapat menguji hubungan makna hidup dan tingkat depresi dengan melibatkan faktor resiliensi dan persepsi terhadap permasalahan. Hal ini dapat dilakukan mengingat resiliensi dan persepsi terhadap permasalahan juga merupakan faktor yang 
berpengaruh terhadap munculnya gejala-gejala depresi.

c. penelitian berikutnya juga dapat mengembangkan psikoterapi yang dapat mengatasi permasalahan terkait depresi yang disebabkan oleh makna hidup pada mahasiswa.

2. Bagi institusi pendidikan

Institusi pendidikan, khususnya tingkat universitas, dapat membuat intervensi yang sesuai untuk meningkatkan makna hidup mahasiswa sebagai bentuk prevensi untuk meminimalisir munculnya gejala-gejala depresi pada mahasiswa, khususnya gejala depresi yang muncul disebabkan oleh perasaan tidak bermakna dalam hidupnya.

\section{DAFTAR PUSTAKA}

Arnold-Baker, C. (2005). Depression and Apathy. In C. Arnold-Baker \& E. van Deurzen (Eds.), Existential Perspectives on Human Issues: a Handbook for Therapeutic Practice. New York: Palgrave Macmillan. https://doi.org/10.1007/978-0230-21624-2

Battista, J., \& Almond, R. (1973). The Development of Meaning in Life. Psychiatry: Interpersonal and Biological Processes, 36(4), 409427.

https://doi.org/10.1521/00332747. 1973.11023774
Bayram, N., \& Bilgel, N. (2008). The prevalence and sociodemographic correlations of depression, anxiety and stress among a group of university students. Social Psychiatry and Psychiatric Epidemiology, 43(8), 667-672.

https://doi.org/10.1007/s00127-

008-0345-x

Beck, A. T., \& Alford, B. A. (2009).

Depression: Causes and Treatment (2nd ed.).

Philadelphia: University of Pennsylvania Press. https://doi.org/10.1017/CBO9781 107415324.004

Bennett, P. (2006). Abnormal and Clinical Psychology An Introductory Textbook (2nd ed.). New York: Open University Press.

Debats, D. L. H. M. (1996). Meaning in Life: Psychometric, Clinical and Phenomenological Aspects. Groningen.

Devivere, B. von. (2018). Meaningful Work: Viktor Frankl's Legacy for the 21st Century. Switzerland: Springer.

Ginting, H., Näring, G., Van Der Veld, W. M., Srisayekti, W., \& Becker, E. S. (2013). Validating the Beck Depression Inventory-II in Indonesia's general population and coronary heart disease patients. International Journal of Clinical and Health Psychology, 
13(3),235-242. https://doi.org/ 10.1016/S1697-2600(13)70028-0

Hedayati, M., \& Khazaei, M. (2014). An Investigation of the Relationship between Depression, Meaning in Life and Adult Hope. Procedia - Social and Behavioral Sciences, 114, 598-601. https://doi.org/10.1016/j.sbspro.2 013.12 .753

Islam, A., Low, W. Y., Tong, W. T., Choo, C., \& Yuen, W. (2018). Factors Associated with Depression among University Students in Malaysia: A Crosssectional Study. In The 2nd International Meeting of Public Health 2016 with theme "Public Health Perspective of Sustainable Development Goals: The Challenges and Opportunities in Asia-Pacific Region" (pp. 415427). KnE Life Sciences. https://doi.org/10.18502/kls.v4i4. 2302

Khurshid, S., Parveen, Q., Yousuf, M. I., \& Chaudhry, A. G. (2015). Effects of Depression on Students 'Academic Performance. Science International, 27(2), 1619-1624.

Kleftaras, G., \& Psarra, E. (2012). Meaning in Life, Psychological Well-Being and Depressive Symptomatology: A Comparative Study. Psychology, 03(04), 337345 .

https://doi.org/10.4236/psych.201 2.34048
Marshall, M. (2011). Prism of Meaning: Guide to the Fundamental Principles of Viktor E. Frankl's Logotherapy. Otawa Institute of Logotherapy.

Meiyuntari, T., \& Utomo, R. H. R. P. (2015). Kebermaknaan Hidup, Kestabilan Emosi dan Depresi. Persona, Jurnal Psikologi Indonesia, 4(3), 274-287.

Moreno, M. A., Jelenchick, L. A., Egan, K. G., Cox, E., Young, H., Gannon, K. E., \& Becker, T. (2011). Feeling Bad on Facebook: Depression Disclosures by College Students on a Social Networking Site. Depression and Anxiety, 28, 447-455. https://doi.org/10.1002/da.20805

Santrock, J. W. (2013). Life-Span Development (14th ed.). New York: McGraw-Hill.

Sarokhani, D., Delpisheh, A., Veisani, Y., Sarokhani, M. T., Manesh, R. E., \& Sayehmiri, K. (2013). Prevalence of Depression among University Students : A Systematic Review and MetaAnalysis Study. Depression Research and Treatment, 2013, 1-7. https://doi.org/10.1155/2013/3738 57

Schaefer, S. M., Boylan, J. M., Van Reekum, C. M., Lapate, R. C., Norris, C. J., Ryff, C. D., \& Davidson, R. J. (2013). Purpose in life predicts better emotional 
recovery from negative stimuli.

PLoS ONE, 8(11).

https://doi.org/10.1371/journal.po ne.0080329

The Insight Network and Dig in. (2019). Mental Health Survey 2018. London. Retrieved from https://uploadsssl.webflow.com/561110743bc7e 45e 78292140/5c7d4b5d314d163f ecdc3706_Mental Health Report 2018.pdf 